\title{
Study on the Transition of Land in the Palih Baru Village
}

\author{
Suprapto \\ Antakusuma University \\ Pangkalan Bun - Borneo Island, Indonesia \\ Praptosuprapto977@yahoo.co.id
}

\author{
Brian L. Djumaty \\ Antakusuma University \\ Pangkalan Bun - Borneo Island, Indonesia \\ Brian.djumaty@gmail.com
}

\begin{abstract}
In this study used a qualitative descriptive method to describe the dynamics that occur when people make buying and selling land. From this research there were some problems encountered such as; 1 ). Certificates owned by the community do not have a clear boundary location. 2). National land agency does not have an archive of land certificates. 3). National land agency was inconsistent regarding making the land letter (land certificates, certificate of land register).
\end{abstract}

Keywords-Boundary Map; Archives; Certificate;

\section{INTRODUCTION}

Land has a high economic value and is essential for a person's life both as individuals and as members of society. Why is said to be of high economic value because the land can be traded and persistent price rise if the region continues to grow economically. Indonesian state has rules in land including Law No. 5 of 1960, on the Basic Regulation of Agrarian [1], then published. Indonesian Government Regulation No. 24 Year 1997 on Land Registration. The purpose of these rules is that people have legal certainty about the land owned.

Furthermore, in the Basic Agrarian Law also regulates the kinds of land rights among which are: Right to control the country; Right of ownership; Cultivation Rights; Right to Use Right building and rental rights. Over land rights mentioned above can be transferred to other parties including by way of: purchase, exchange swapping, grants.

One form of buying and selling land that can be done in the transition of ownership of the land as follows: 1) Sale and purchase of property rights to land is a transfer of property rights to land by the seller to the buyer for ever and the buyer submit the price to the seller [2]. 2) inheritance is a transfer of wealth as a whole, which means the transition all the rights and obligations of people who give or bequeath a legacy to those who receive an inheritance or heirs. In general it can be said inheritance implies that the transfer of ownership of the possessions of the inheritance then determine what portion of each. The transition of land rights for inheritance occurs by operation of law, which means the death of the heir to the heirs acquire ownership rights over property and wealth heir. The transition on the form of land inheritance rights evidenced by heir statement made by the heirs and known or verified by officials berwenang.dengan heir statement, and then be registered at the local land office to be recorded in the land book rights holders new neighbor ie on behalf of the heirs, it is very important to do for the heirs have the force of law, According to Vollmar [3], 3) transition process of land rights was made before Land Deed Official (PPAT) by using a Sale and Purchase Agreement, then found a legal breakthrough and still continues to be in the practice of buying and selling that is binding sale and purchase agreement (PPJB), although it is already set up on land sales, but the new format is limited binding sale and purchase agreement is a form that is or can be said as a preliminary agreement [4].

Based on the explanation above, this study will describe and analyze 1). how the procedure BPN issued Titles (SHM) 2). how the transition process of land rights from the owner to the buyer 3) What are the problems encountered when the process of changing the name on the certificate

\section{METHOD}

A. Before make research

In addition to a teacher, one of the authors also worked as a maid at the notary. This study started from a few applicants that is between the seller and buyer to change the name on the certificate of land rights. on the basis of these problems so that researchers interested in conducting research using descriptive qualitative method.

\section{B. Maintaining the Integrity of the Specifications}

This study uses a qualitative method. [5] Qualitative is a way to retrieve data from a primary (first hand). Discovery or qualitative research results from not using statistical procedures [6]. Other qualitative understanding is the study of empirical studies in the field by region multimetode, interpretation and naturalistic approach [7]. There are several terms in qualitative methods such as: 1) naturalistic, 2) ethnography, symbolic interactionist, 3) life history, 4) case studies, 5) interpretative, 6) ecology and 7) Descriptive. This research uses descriptive data such as the words of the informant / speaker observed and revealed the specific problems and circumstances that can give a precise picture of the object under investigation. 
III. RESEARCH FINDINGS \& DISCUSSION

This section will discuss the results of in-depth research and analysis related to the dynamics of buying and selling land.

\section{A. The procedure of making the certificate}

Every community has a plot of land required to apply to the land registry office (National Land Agency) so that the legality of the guaranteed security of rights and obtaining of evidence that (land certificate) [8]. There are several conditions that must be met when people want to make the land certificate. Referring to the provisions of the Ministry of Agrarian And the Spatial National Land Agency on Procedures and Application Procedures. If it has met all regulatory requirements, the applicants are entitled to a Certificate of Property Rights (SHM).

Based on the results of research conducted by the author in the village of New Palih by some members of the public that Mr. PJ pseudonym (58 years) and Mrs. KM pseudonym (38 years old) who has a certificate issued by the Land Agency Nasinal. When referring to the rules of Government Regulation No. 24 of 1997 on registration of land can be seen that given the rights to land in different types of rights. Based on the above regulation it can be said that the certificates owned by the public have legal certainty.

\section{B. Regulatory Transition and transferred to the Other}

Law No. 5 of 1960 Article 20, paragraph 2 of the basic rules explained on the subject of agrarian property rights can be switched and transferred to another party. [9] buying and selling land can only be done through Land Deed Official (PPAT) between seller and buyer with proven by deed. In general maintenance procedures transitional land rights can be seen in the following diagram:

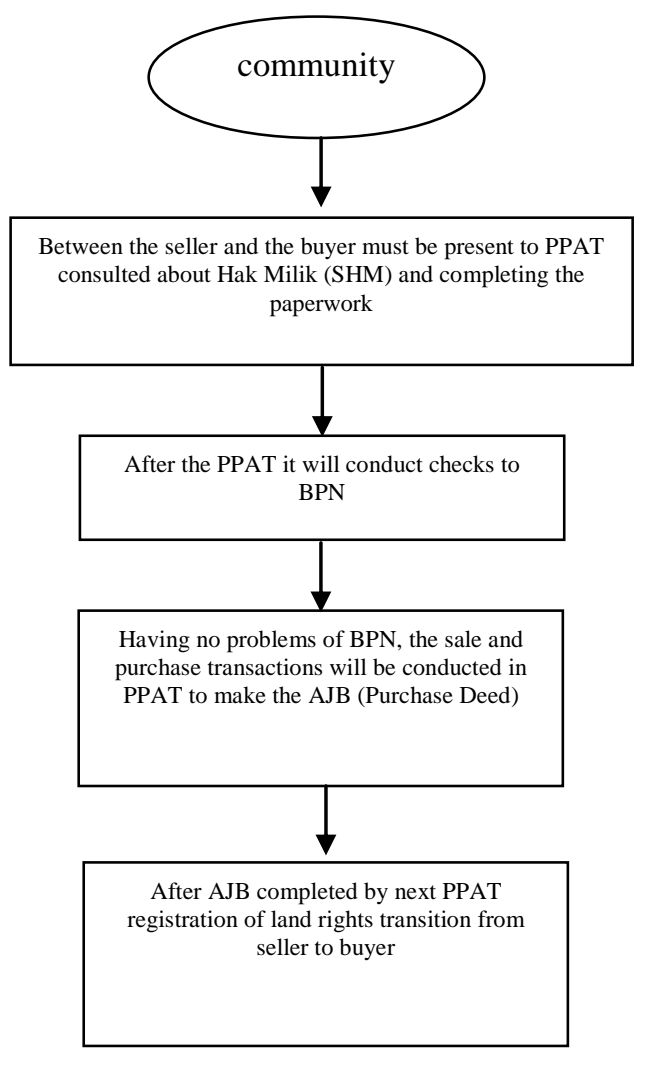

\subsection{Flow Diagram transitional land rights}

In Figure 1.1 can be explained that the procedure to hand over land rights must go through four stages.

\section{Transition Dynamics of land rights}

Sale and purchase of land by the seller (PJ, 58 years) due to the child's needs and the needs of the school-day sebahari. Here is an excerpt:

I sell the land because of the cost of school children is expensive, essential commodities rose. Based on this, so I sold the land

So is the case with (Mrs. KM, 38 years). Basic land for sale because of unexpected needs, increasing the cost of school children, etc. The following is an excerpt of the interview:

This land is sold due to several factors: 1) the needs of the unexpected. 2) the costs of expensive school children. 3) as well as other needs.

Based on interviews by investigators, land transfer between the seller and buyer conducted in 2005 and 2009. The following is a table of buyers and sellers

\begin{tabular}{lll}
\hline name Sellers & name Buyers & year deal \\
\hline PJ & DD & 2005 \\
KM & WP & 2009 \\
\hline
\end{tabular}

Table 1.1 sellers and buyers and the transaction 
Buying and selling process between buyer and seller is done by agreement between the two parties that the agreement under hand. In line with the results of research by Hastuti [10] Shows that the process of buying and selling land taken a hand because the cost is not too big and fast process. But on the legitimacy of the process of buying and selling land can be said to be unlawful because it was not done through the land deed official (PPAT). In 2016 the buyer the process of switching land rights and will replace the name on the certificate. In accordance with the procedure if the transition of land rights, the two defense parties (buyer and seller) must attend at PPAT and complete the requirements according to regulations. However, upon checking into BPN personnel (employees) cannot be questioned and further processing certificates owned by PJ and PM. In addition BPN Party does not have an archive of the certificate.

\section{Framework Based on Field}

Here's a field findings framework which is critical notes and reflections by the author of the research.

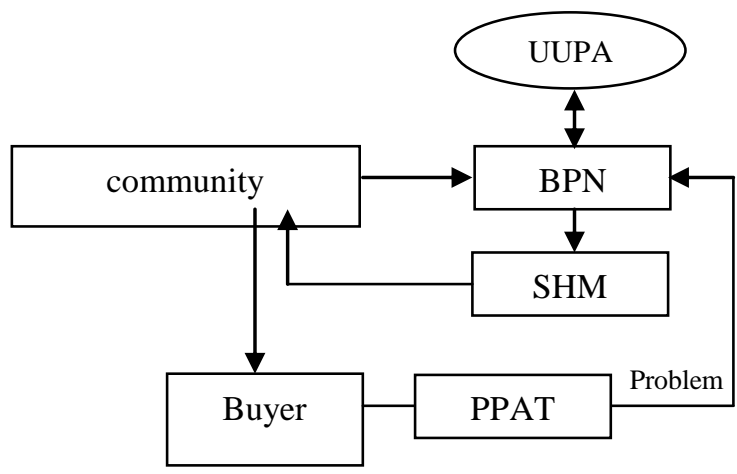

Figure 1. Framework Based on Field

Based on the framework in Figure 1. It can be explained that the procedure of the National Land Agency issued a Certificate of Land Ownership (SHM) refers to the Basic Agrarian Law (BAL). when the National Land Agency (BPN) issuing the legality certificate (legally recognized).

Time goes by people who have a piece of land plans to sell the land. Before performing the transfer of rights in the name of the certificate, the seller and the buyer must be present at the office of Land Deed Official (PPAT) to consult the certificate. Once the requirements are met then it will check through Land Officer Aakta (PPAT then processed kroscek the certificate to the National Land Agency (BPN).

But when did the transition of land rights by the buyer, there are several constraints such as: 1) BPN can not process the certificate that has been issued by BPN itself 2) BPN does not have an archive of the complete field map.

\section{CONCLUSION}

Research on land has been carried out by researchers, academics and an NGO. This study found some problems faced by the community when making changes to the name of land rights among others are The National Land Agency can not process to change the name on the certificate, The National Land Agency mempertanayakan certificate from the community because there is no clear boundary footprint, and The national land agency does not have a certificate from the public archives. However, the certificate issued by the National Land Agency (BPN). If this is not observed and followed up by the relevant authorities it will cause problems between government agencies and the community.

\section{ACKNOWLEDGMENT}

The author would like to thank the Foundation Kotawaringin Antakusuma University, Rector of the Antakusuma University.

\section{REFERENCES}

[1] Bahroni, Achmad. "Used Land plantations Erfpacht Rights Reserved The Dutch Foreign Residents Occupied People". Periodical Scientific Journal University of Kadiri. Edition: February 2014. http://jurnal.unikkediri.ac.id/wpcontent/uploads/2015/07/JURNAL HA K ERPACT TANAH_BAHRONI.pdf

[2] Kahar, Abdul., Ismail, Ilyas \& Suhaimi. Transfer of Rights Owned Assets Together Through Land Purchase By Husband Or Wife. Science Journal Shiite kuala University law graduate. Volume 2. No. 1. August 2013

[3] Setiyarini, Eka.Puji., Budiono, Abdul. Racmad \& Soekesi, Titik. Puji. As a result of the transitional law due to inheritance rights to land that is not registered at the office of the land under section 42 of Government Regulation 24 of 1997 concerning land registration. Ministry of education and culture. Master kenotarian brawijaya university law faculties. Malang. 2014

[4] Mulyono, Bambang.Eko. implementation of transitional land rights based binding sale and purchase agreement and the power to sell made by a notary. Independent Journal. Volume 2 No. 2. 2014

[5] Raco, J.R. Metode Penelitian Kualitatif. Jakarta. GRASINDO. 2010

[6] Kembal, Rahel. Widiawati. Social Capital and the Small Industrial Economics A Qualitative Study. Yogyakarta. Deepublish. 2015

[7] Endraswara, Suwardi. Methods, Theory, Culture Research Techniques; Ideology, Epistemology and application. Yogyakarta. Reader Widyatama. 2006

[8] Mulyono Bambang Eko. 2013. Implementation of Transfer of Rights to Land Based on the Sale and Purchase Agreement And Authorization To Sell Made By Notary.http://www.ejurnal.com/2016/01/pelaksanaan-peralihan-hak-atastanah.html

[9] Kahar. Abdul, Ismail. Ilyas and Suhaimi. Transfer of Rights Owned Assets Together Through Land Purchase By Husband Or Wife. Journal of Legal Studies, Graduate of University of Syiah Kuala. Vol. 2, No. 1. August 2013

[10] Hastuti, P.R.D. Validity of the Sale and Purchase Land Rights Under Hand Village Patihan Sidoharjo District of Sragen: Overview of several related cases in state court in Surakarta. Repertorium Journal. Volume II. No.2. July-December 2011 